\title{
Biology and Integrated Control of Tomato Wilt Caused by Fusarium oxysporum lycopersici: A Comprehensive Review under the Light of Recent Advancements
}

\author{
Hanan Aref Hassan * \\ Department of Plant Production, Faculty of Agriculture, Jerash University, Jordan
}

\begin{abstract}
Tomato (Lycopersicon esculentum L.) is one of the most popular and important commercial vegetable crops grown throughout the world. Tomato is a rich source of various micronutrients and antioxidants. One of the major causes of poor quality and fruit loss during storage and transport are diseases caused by phyto-pathogenic fungi. Fusarium wilt of tomato caused by Fusarium oxysporum lycopersici becomes one of a limiting factor in the production of tomato and accounts for yield losses in Jordan and the whole world. It is considered as one of the most prevalent and damaging diseases wherever tomatoes are grown because the pathogen persists in infested soils. Pathogenic fungi of the genus Fusarium, cause root and basal stem deterioration and result in the wilting of vegetable plants. Browning of the vascular tissue is a strong evidence of fusarium wilt. Because of hazards of pesticides in general, and fungicides in specific, on public health and environmental balance, new direction of pest control management was introduced. Biological management of Fusarium wilt of tomato using bio-fortified composts associated with selected biological control agents (Fungal and bacterial species) is studied. Recently, different reports stated that some plant extracts and plant essential oils have been reported to be effective antimicrobial agents against food and stored grain fungi, foliar pathogens, and soil-borne fungal phyto-pathogens. This review is aimed at investigating the occurrence of Fusarium wilt of Tomato in Jordan and summarizing the best ways of management and control, especially the biological means.
\end{abstract}

Keyword

Fusarium oxysporum, Fungicide, Tomato, Fusarium wilt, Plant extract

\section{Introduction}

Tomato (Lycopersicon esculentum L.), which belongs to family Solanaceae and genus Solanum [1-5] is native to South America and was first discovered in Mexico [6]. The cultivated form was first taken to Europe by Spanish in the $16^{\text {th }}$ century and from there introduced into southern and eastern Asia, Africa and the Middle East and distributed throughout the world [7-10]. According to Al-Shadiadeh, et al. [10], world production exceeds 133 million metric tons which covered around 4.7 million hectares from the whole production in 2007.

Tomato is considered as one of the highly valuable nutritive and widely grown vegetables in 144 countries of the world. The most tomato producing countries of the world in metric ton production are China, United States, Turkey, India and Egypt. The total area under cultivation of tomato is $45,82,438$ thousand ha. Whereas, the production 15051381 thousand tones and productivity of 32.8 tones/ha has been recorded in the world [11]. China is considered as the largest area of production in the world which occupying $871,235,000$ hectares with a production of $41,879,684,000$ tonnes [4].
But the highest productivity is come out from USA which is 81 ton/ha. In India, the total production of tomato is 16826 thousand tons which comes from 865 thousand hectares of land [12].

In Egypt, tomato is the most important vegetable crop. About 186.000 ha is cultivated and the average production reaches up to seven million tons, which are consumed either fresh or processed [13]. Economically tomato is the second most important vegetable produced worldwide at around 115.95 million tons per year as it is a short duration crop and gives a high yield, it is economically attractive and the area

*Corresponding author: Hanan Aref Hassan, Department of Plant Production, Faculty of Agriculture, Jerash University, Jerash 26150, Jordan

Accepted: July 16, 2020

Published online: July 18, 2020

Citation: Hassan HA (2020) Biology and Integrated Control of Tomato Wilt Caused by Fusarium oxysporum lycopersici: A Comprehensive Review under the Light of Recent Advancements. J Bot Res 3(1):84-99 
Citation: Hassan HA (2020) Biology and Integrated Control of Tomato Wilt Caused by Fusarium oxysporum lycopersici: A Comprehensive Review under the Light of Recent Advancements. J Bot Res 3(1):84-99

Table 1: Most Common Pests and their Causal Agents which Attacks Tomato in Jordan [154].

\begin{tabular}{|c|c|}
\hline $\begin{array}{l}\text { Fungi } \\
\text { Fusarium wilt } \\
\text { Black mold } \\
\text { Early blight }\end{array}$ & $\begin{array}{l}\text { Fusarium oxysporum } \\
\text { Alternaria alternata } \\
\text { Alternaria solani }\end{array}$ \\
\hline $\begin{array}{l}\text { Bacteria } \\
\text { Bacterial canker } \\
\text { Bacterial speck }\end{array}$ & $\begin{array}{l}\text { Clavibacter michiganensis } \\
\text { Pseudomonas syringae }\end{array}$ \\
\hline $\begin{array}{l}\text { Oomycetes } \\
\text { Buckeye rot (Phytophthora root rot) } \\
\text { Late blight }\end{array}$ & $\begin{array}{l}\text { Phytophthora spp. } \\
\text { Phytophthora infestans }\end{array}$ \\
\hline $\begin{array}{l}\text { Viruses } \\
\text { Tomato mosaic virus } \\
\text { Tomato spotted wilt } \\
\text { Tomato Yellow Leaf Curl disease }\end{array}$ & $\begin{array}{l}\text { Tomato mosaic virus (ToMV) } \\
\text { Tomato spotted wilt virus (TSWV) } \\
\text { Tomato Yellow Leaf Curl Virus (TYLCV) }\end{array}$ \\
\hline $\begin{array}{l}\text { Insects } \\
\text { Beet armyworm } \\
\text { Tomato fruit worm (Corn earworm) }\end{array}$ & $\begin{array}{l}\text { Spodoptera exigua } \\
\text { Helicoverpa zea }\end{array}$ \\
\hline $\begin{array}{l}\text { Nematodes } \\
\text { Root knot nematode }\end{array}$ & Meloidogyne spp. \\
\hline $\begin{array}{l}\text { Mites } \\
\text { Spider mites (Two-spotted spider mite) }\end{array}$ & Tetranychus urticae \\
\hline
\end{tabular}

under cultivation is increasing. Its position in the whole world is after potato and sweet potato both in area and production $[14,15]$. In Pakistan, tomato is grown on area of 62.6 thousand hectares which produces 587.1 thousand tons with an average yield of 9.4 thousand tons per hectare [11]. In Jordan, according to the department of Statistics, Ministry of Agriculture [16], the average cultivated area was 19.63 Dunm with an average yield of 119.24 tonnes.

Earlier studies reported major important tomato diseases such as early blight (Alternaria solani) $[5,13,17,18]$, late blight (Phytophthora infestans), and Septoria leaf spot (Septoria lycopersici). Some diseases have become the most important ones; these diseases include powdery mildew (Leveillula taurica), root knot nematode (Meloidogyne spp.) and bacterial wilt (Ralstonia solanacearum). However, Fusarium wilt of tomato is one of the most important diseases, which affect all plant stages (seedling stage, flowering stage, and fruiting stage). Also, it can affect the whole plant parts, leaves and stems $[9,12,13,17,19-24]$. Agrios [25] reported that the disease is most destructive in warm climates and warm sandy soil of temperate regions. The recorded diseases that attack different agricultural crops especially tomato in Jordan are shown in (Table 1).

Fusarium wilt around the world is considered as one of the most important diseases of tomato [17-19,21,22,24,2629]. The causal agent of this disease is Fusarium oxysporum lycopersici [12,19,20,24,29-32].

It is a soil-borne phytopathogen causing vascular wilt by infecting plants through the roots, growing internally through the cortex to the stele, and killing the plants $[20,23,24,29,32$ -
34]. Worldwide, tomato yield is reduced to 30 to $40 \%$ due to $F$. oxysporum [35]. To avoid these losses, several studied strategies have been used such as: (1) Disinfection of soil and planting material with fungicidal chemicals like benomyl, captafol, imazalil, thiram, etc. [36], (2) Crop rotation, (3) Use of resistant cultivars $[37,38]$ and (4) Use of healthy biological control agents derived from microbes or medicinal herbs $[3,20,23,24,29,30,32,33,39,40]$.

This review paper is aimed at summarization of tomato Fusarium wilt; a disease caused by Fusarium oxysporum Lycopersici. Different ways of management and control in general and in specific, the use of various medicinal plants extracts (ecofriendly) biological control methods in Jordan.

\section{Tomato Plant: Botanical Notes}

Tomato plant (Lycopersicon esculentum L.) which belongs to family Solanaceae and the genus Solanum is an annual plant, which can reach a height of over two meters $[11,17,19,21,22,26-29,34]$. The first harvest is possible 45-55 days after flowering, or 90-120 days after sowing. The color ranges from yellow to red $[11,41]$. Three different types of tomato plants can be distinguished as tall or indeterminate type, semi-bush and bush (determinate) type. The tall varieties are the best choice for a long harvest period, they exhibits a good feature called indeterminate; and that they keep growing after flowering. The more foliage the plant exhibits keeps the temperature lower within the crop and the fruits grow in the shade of the leaves. Hence, the sun does not damage the fruits and they ripen more slowly. Slower ripening and a high leaf/fruit ratio improve the taste of the fruits and its sweetness [41]. 


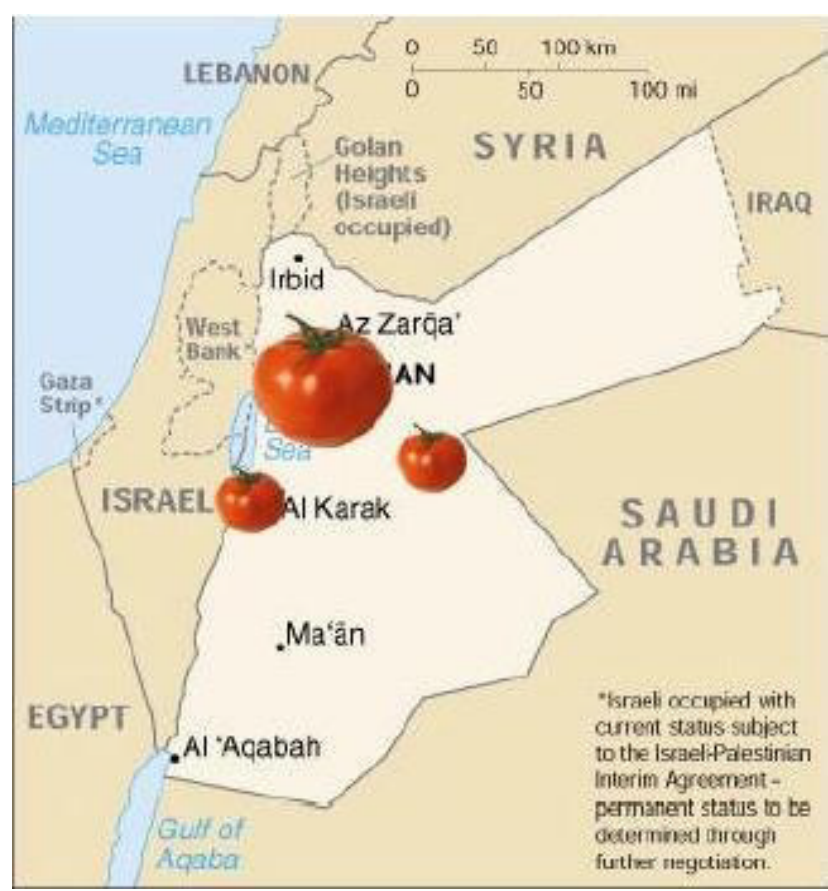

Figure 1: Tomato production in Jordan [155].

\section{Tomato in Jordan: Cultivation and Economic Importance}

Jordan is a regional tomato producer; and the world's $4^{\text {th }}$ largest exporter of fresh tomatoes [42]. Important varieties grown in Jordan include Shams, RS589956, Jawaher and Casandra. Tomato is grown throughout the country, in outdoor fields, greenhouses and net-houses where irrigated water and arable lands is available. Tomatoes can be cultivated in different soil types and artificial well-draining substrates. Optimum day temperature for growth is 18 to $25^{\circ} \mathrm{C}$ and night temperatures between 10 and $20^{\circ} \mathrm{C}$. Furrow and drip techniques are used for irrigation. Harvesting crop is done 70-140 days from transplanting depending on the crop variety and on cultivation conditions used. Tomatoes are planted throughout the year in Jordan as the following: Southern part of Jordan Valley: January-February; Middle part of Jordan Valley: May-June; Northern part of Jordan Valley: June-July and Safa Crop (hilly areas): July-November (Figure 1) [42].

In Jordan tomatoes production covers about $27.5 \%$ of the total vegetable cultivated area and about $3 \%$ of the total cultivated area. The highest vegetable production is for Tomato at $43.4 \%$ of total vegetable production in 2012 and is followed by cucumber (9.2\%), potato (8.3\%), eggplant (7.1\%), and water melon (6.4\%). According to the Department of Statistics, Agricultural Survey data, the total area under production of both greenhouse and open field, tomatoes in Jordan increased from 7,656 ha in 2002 to 12,345 ha in 2012, indicating a growth of $161 \%$.

The total tomato cultivated area has increased from 11,752 ha in 2008 to 12,345 in 2012, reflecting a growth of approximately $5 \%$. The average yield has increased from 51.7 ton/ha in 2008 to a good yield rate of 59.8 ton/ha in 2012 [43]. According to Department of Statistics, Ministry of Ag- riculture in Jordan (2018) the average cultivated area was 19.628 ha with an average yield production of 119.242 tons reflecting a good yield increase of Tomato.

\section{Importance and Use of Tomato Plant: Nutri- tive Value}

Tomato is considered as highly nutritive, protective and the freshest vegetable with a widespread production in Jordan and in different countries around the world, [11,29,44]. It has much nutritional value at very cheap price as compared to other vegetables. It has $95.3 \%$ water, $0.07 \%$ calcium and niacin, Vitamin A, C, E and rich source of nutrients like $\mathrm{Na}$, $\mathrm{K}, \mathrm{Fe}$, and antioxidants especially lycopene and salicylate. All of have great importance in human metabolic system. Every 100 -gram of raw tomatoes contain $93.59 \%$ water, 22 calories, $1.1 \mathrm{~g}$ protein, $4.7 \mathrm{~g}$ carbohydrates, $13 \mathrm{mg}$ calcium, $27 \mathrm{mg}$ phosphorous, $0.5 \mathrm{mg}$ ferrous, $244 \mathrm{mg}$ potassium, $900 \mathrm{mg}$ vitamin A $0.06 \mathrm{mg}$ thiamine, $0.04 \mathrm{mg}$ riboflavin, $0.7 \mathrm{mg}$ niacin, 23 $\mathrm{mg}$ ascorbic acid $[29,45]$. In addition, the red pigment of the lycopene which tomato fruit contains has attractive interest because the lycopene has high antioxidant ability against oxygen radicals that may cause cancer, aging, arteriosclerosis, etc $[11,41,46-50]$.

\section{Fusarium Genus: Morphological Characteris- tics and Distribution}

Fusarium is a filamentous fungus (Sordariomycetes:Hypocreales:Nectriaceae) containing different phytopathogenic and toxigenic species. The genus is highly diverse with twenty monophyletic species complex and outgroups of nine species. The commonest species include Fusarium solani, F. oxysporum, F. equiseti and F. chlamydosporum [18,51-53]. Key features for the differentiation of Fusarium species are color of the colony, length and shape of the macro conidia, the number, shape and arrangement of microconidia, and presence or absence of chlamydospores are [53].

Fusarium is one of the most important pathogenic fungi. Toxic metabolites such as enniatins and fusaric acid can be produced by different species of this genus causes severe diseases, and can contaminate agricultural product, making them unsuitable for food and feed. Moreover, trichothecenes can act as virulence factor in plant disease [53-55].

Diverse molecular methods can be used for rapid identification of Fusarium strains to species and sub-species levels such as 28S rRNA gene sequencing [56], polymerase chain reaction (PCR) based rDNA detection method [57] and detection of protein banding patterns by SDS-PAGE and esterase isozyme electrophoresis [18,53].

\section{Fusarium Genus: Growth Characteristics}

Windles [58] reported that the fungus grows on artificial medium on PDA. It grows rapidly covering $9 \mathrm{~cm}$ diameter Petri-dish in about 7 days and forms a hyaline, branching mycelium that is white to gray. On PDA medium isolates from diseased fruits formed light pink aerial mycelium and red pigment in the agar. On Czapek agar isolates formed colonies and mycelium appeared as aerial, grey to light purple in color 
Citation: Hassan HA (2020) Biology and Integrated Control of Tomato Wilt Caused by Fusarium oxysporum lycopersici: A Comprehensive Review under the Light of Recent Advancements. J Bot Res 3(1):84-99

depending on the isolate. Fusarium cultures grown on Sabouraud Dextrose Agar medium at optimum temperature 25 ${ }^{\circ} \mathrm{C}$ produce cottony, flat, woolly, or spreading colonies $[59,60]$.

Fusarium has diverse life cycles, niche specialization, host adaptation and specificity. Fusarium graminearum and F. ver-
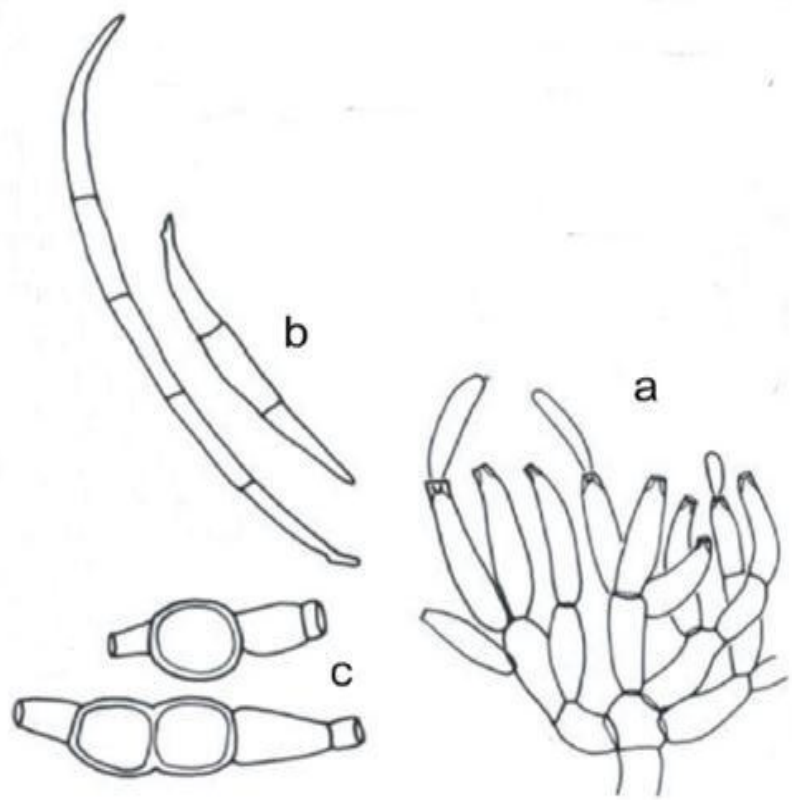

Figure 2: The three different spores produced by Fusarium oxysporum. A. Microconidia. B. Macroconidia. C. Chlamydospores [41]. ticilloides are pathogen that infects cereals, whereas F. oxysporum infects both monocotyledonous and dicotyledonous plants [61]. Fusarium oxysporum is asexual; others are both asexual and sexual with either self-fertility (homothallism) or out-crossing (heterothallism). Fusarium species produce meiotic (sexual) spores and at least three types of mitotic (asexual) spores. However, all Fusarium species do not produce all type of spores: also, less than $20 \%$ of Fusarium species reproduce sexually $[11,53,62]$.

\section{Fusarium oxysporium}

Fusarium oxysporum lycopersici is one of destructive soil borne fungal pathogen, causing wilt disease in tomato $[11,18,62]$. It produces white aerial mycelium with pink, orange, red, blue, and purple pigmentation developing with age. Fusarium oxysporum lycopersici can produces three types of asexual spores, macro- and micro-conidia and chlamydospores depending on culture conditions (Figure 2). Macro-conidia are produced long, sickle-shaped, thin-walled, spores with several septa. Micro-conidia are abundant and are smaller single-celled, oval-shaped spores. The production of micro-conidia on short monophialides is a distinguishing characteristic. Chlamydo spores are thick-walled, round; dormant spores are formed singly or in pairs. It is typically produced in 2-4 weeks on old culture $[11,13,62,63]$.

The life cycle of $F$. oxysporum (Figure 3 ) begins with a spore landing on a leaf surface of a host plant. When environmental conditions of temperature and available moisture are favorable, the spore germinates; its hyphae elongate and

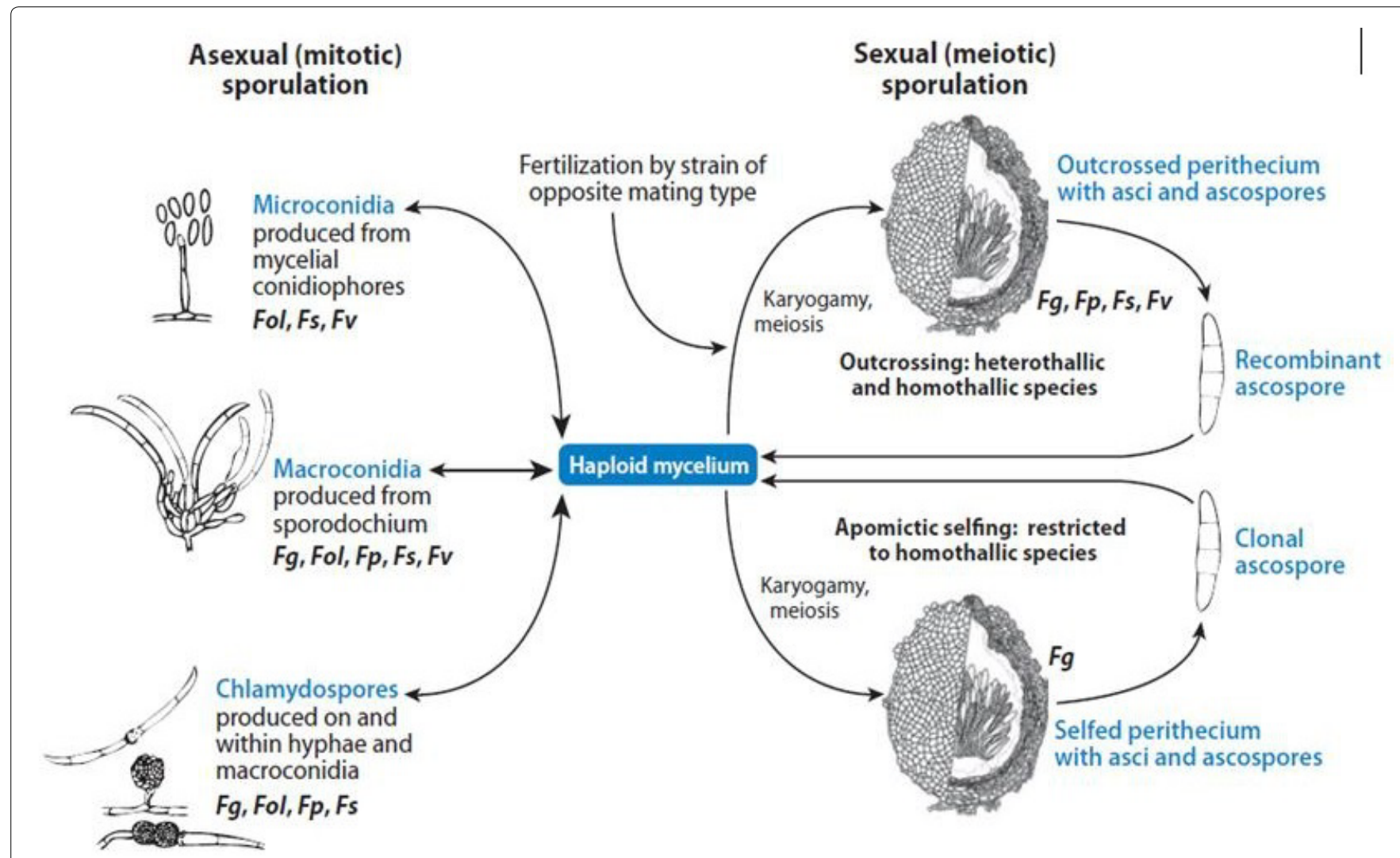

Figure 3: Life cycle of Fusarium [41]. 
Citation: Hassan HA (2020) Biology and Integrated Control of Tomato Wilt Caused by Fusarium oxysporum lycopersici: A Comprehensive Review under the Light of Recent Advancements. J Bot Res 3(1):84-99

penetrate into the leaf cuticle, stomata, or wounds. Once hyphae enter the leaf, the infection process begins. During the latent stage, the affected leaf area does not show any symptom until a length of time known as the incubation period has elapsed. The affected leaf area then develops symptoms and the pathogen begins to sporulate during the infectious stage $[4,62,64]$.

F. oxysporum is the causal agent of vascular wilt, a disease that affects a large variety of important crops worldwide $[12,18-20,29-32,62,64,65]$. The high level of host specificity of pathogenic strains in $F$. oxysporum led to the development of the "formae speciales" concept to enable better differentiation of these morphologically similar strains [1]. The "formae specials" are characterized by their ability to cause a wilt disease on a limited taxonomic range of host plants $[18,62,64,66]$.

Strains of $F$. oxysporum which were isolated from healthy parts are called non-pathogenic and can protect plants against the pathogenic ones. Several non-pathogenic strains of $F$. oxysporum, isolated from soils suppressive to Fusarium wilt, have been selected as potential biological control agents $[53,67]$. In Jordan; there are three known physiological races of $F$. oxysporum lycopersici that are distinguished by their differential pathogenicity to tomato cultivars containing race-specific dominant resistance genes [68]. According to Al-Khatib [69], only races 1 and 2 were recovered. A total of 33 varieties were imported from various sources to investigate the effect of this disease and determine the source of their resistance during the period 1998-2002.

GS12 F1 Variety was the highest amount of seed imported with an imported amount of $275 \mathrm{~kg}$, followed by Wafa F1 variety (70 kg), Guardian F1 (65 kg), Super Red F1 (37.5 kg) and RS589956 (33 kg) (National Center for Agricultural Research and Technology Transfer, Seed Certification Unit, 2003) in Alkhatib, et al. [69].

\section{Fusarium wilt disease}

Fusarium wilts disease caused by F. oxysporum lycopersici is one of the most prevalent and damaging diseases of to- mato plant that causes considerable losses, under favorable weather conditions $[18,20,23,24,29,32,34,62,64,69,70]$.

Several studies tried to explain wilting of tomato plant infected with Fusarium oxysporum lycopersici. Gaumann [71] suggested that wilting results from destruction of permeability of leaf cell by fungal toxin. Other reports suggested that wilting is caused by occlusion of xylem vessels by mycelia and conidia, tyloses, gums and hydrophilic material that may form gels in vessels [64,72]. However, Gothoskar, et al. [73] reported that wilting tomato plant is due to increased viscosity of tracheal fluid and eventual mechanical plugging of vessels by pectic gels. Chambers and Corden [74] found that in diseased stems and petioles, the vascular bundles fail to increase in size and few vessel elements that are produced remain small and collapsed. Horsfall and Dimond [75] reported that the blocking of the xylem ducts, the toxins or enzymes carried along with the flow sap are responsible for wilting.

The pathogenic fungus moves in infected plants through the root system and grows internally through the cortex to the stele using its sporangial germ tube or mycelium $[20,76]$. The root can be infected through root tips, wounds in roots or at the formation point of lateral roots. Mycelium enters the xylem vessels branches and forms microconidia spores [20]. Fungal growth in the vascular system affects water supply which induce the leave stomata to close and plugging the vascular system which results in leave wilting and the plant dies (Figure 4) [18,20,53,64,77].

\section{Disease Development}

Disease development is favoured by warm teperatures $\left(27-28{ }^{\circ} \mathrm{C}\right)$, dry weather, and acidic soil ( $\left.\mathrm{pH} 5-5.6\right)$. Chlamydo spores stay dormant and immobile in the remains of decayed plant tissue until stimulated to germinate by utilizing nutrients that are released from extending roots of a variety of plants $[18,62,64,77-80]$.

Invasion of the roots is followed by the penetration of the epidermal cells of a host or a non-host and the development of vascular disease in host plants [81]. The process of vascular infection by $F$. oxysporum includes adhesion in which fungal

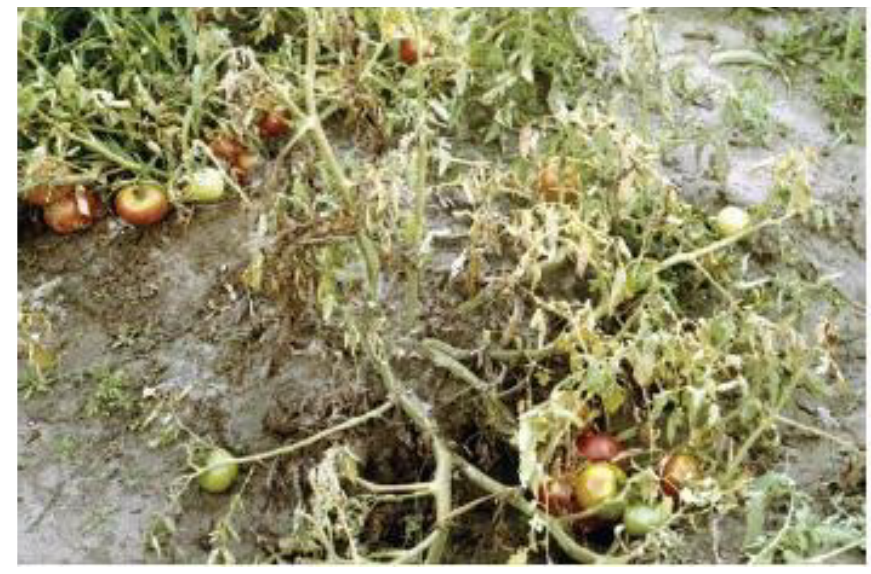

(a)

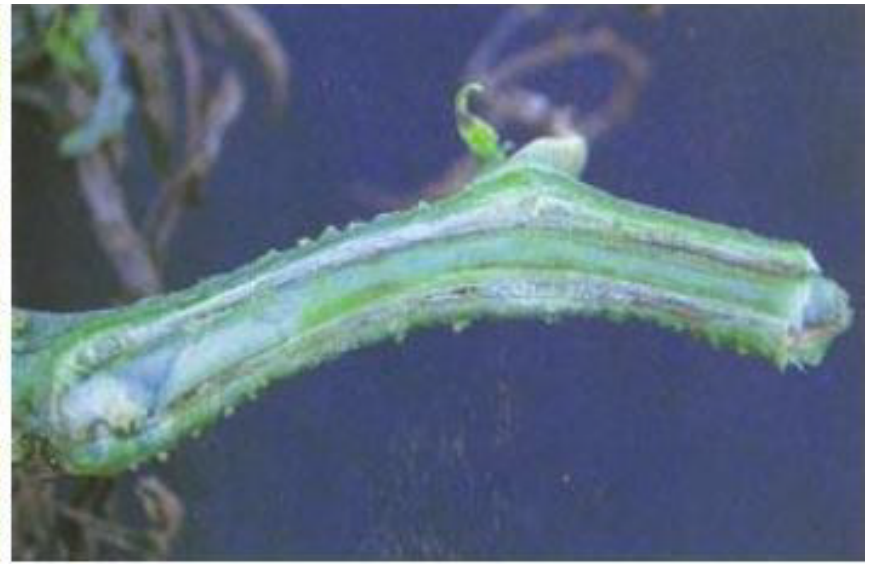

(b)

Figure 4: Fusariums wilt of Tomato caused by Fusarium oxysporum lycopersici (a) Infested farm land (b) Vascular discoloration stem [53]. 
Citation: Hassan HA (2020) Biology and Integrated Control of Tomato Wilt Caused by Fusarium oxysporum lycopersici: A Comprehensive Review under the Light of Recent Advancements. J Bot Res 3(1):84-99

infection starts when hyphae adhere to the host root surface $[77,82]$. Penetration is controlled by a combination of different factors that include fungal compounds, plant surface structures, activators or inhibitors of fungal spore germination, and germ tube formation. Some pathogenic forms penetrate roots directly, whereas others must enter indirectly through wounds $[65,83]$.

The last stage is colonization; the mycelium advances intercellular through the root cortex until it reaches the xylem vessels and enters them through the pits. Fungal colonization of the host's vascular system is facilitated by the formation of microconidia within the xylem vessel elements that are detached and carried upward in the sap stream $[4,18,20,62,64,84]$.

\section{Virulence genes in Fusarium oxysporum}

Indurm and Howlett [85] reported about 79 genes described at that time, and divided them into several categories, depending on their involvement in the formation of infection structures, cell wall degradation, response to the host environment, toxin biosynthesis, signal cascades, and novel functions. However, studies on genes related to pathogenicity in F. oxysporum have been limited. Two of the most important virulence genes associated with $F$. oxysporum is FOW1and ARG1.

Manikandan, et al. [86] attempted to realize the mechanism of wilt caused by $F$. oxysporum, the total proteome of twenty isolates were analyzed along with the cultural, morphological, virulence and molecular characteristics. The seventeen different proteins showed by $2 \mathrm{D}$ analyses they reported the occurrence of the FAD binding domain containing protein, Cutinase-2, Chaperone, Cytochrome P450, sulfate anion transporter, Glycoside hydrolase family 85 protein, $60 \mathrm{~S}$ ribosomal protein and, ATP-dependent RNA helicase. These are the key proteins in virulence, symptom and wilt develop- ment. These proteins were involved in sporulation, growth, maintenance of genome integrity and maximum penetration rate on host root tissues.

The occurrence of Fusarium wilt diseases is affected by soil temperature, since there is a strong relationship between substrate temperature and disease intensity; indicating that there were low and high temperature extremes at which wilt symptoms did not develop, and an optimum temperature at which the most severe disease occurred. The optimal growth of $F$. oxysporum was found to be between $25^{\circ} \mathrm{C}$ and $28^{\circ} \mathrm{C}$ $[34,64,77]$.

Moreover, germination of chlamydospores of F.oxysporum is influenced by soil $\mathrm{pH}$. Mycelia of $F$. oxysporum grew within the range of $\mathrm{pH} \mathrm{2-12} \mathrm{[77].} \mathrm{Wilson} \mathrm{[87]} \mathrm{reported} \mathrm{that}$ acid soil ( $\mathrm{pH} 4.2$ ) supported growth of Fusarium through the soil, whereas a pH near neutrality prevented this growth. Woltz and Jones [88] concluded that Fusarium wilt disease is associated with acidic, sandy soils, rather than heavier soils with higher $\mathrm{pH}$ values. Fusarium growth stages in soil depend on the ecological balance and nutrient availability. F. oxysporum is an autotroph, requiring only a carbon source for structure and energy, and inorganic compounds to synthesize organic compounds such as sugars, lipids and amino acids [88].

Growth, sporulation and virulence of $F$. oxysporum need essential nutrient elements such as carbon, hydrogen, oxygen, nitrogen, phosphorus, potassium, magnesium, sulphur, iron, manganese, molybdenum, and zinc [89]. High levels of nitrogen fertilization in agricultural soils lead to an increase in Fusarium wilt development [90].

\section{Symptoms of Fusarium oxysporum and disease development}

Fusarium wilt caused by the soil borne fungus Fusarium oxysporum lycopersici, was the most prevalent and damag-

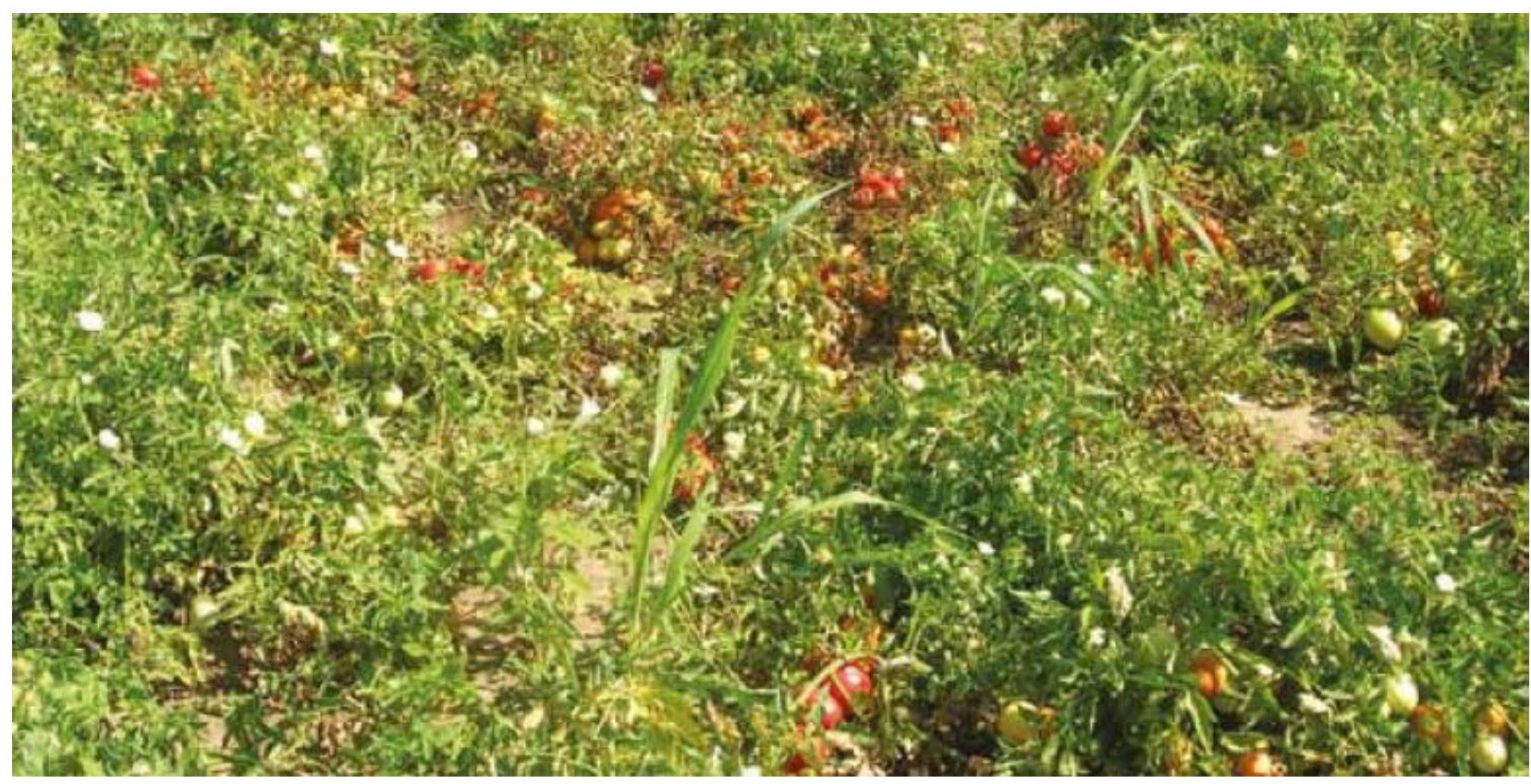

Figure 5: Symptoms of Fusarium wilt on tomato plant in open field [48]. 
ing disease of tomatoes [20,23,24,29,32,34,77,91] (Figure 4 and Figure 5). F. oxysporum enter through the roots and interfere with the water conducting vessels of the plant. As the infection spreads up into the stems and leaves it restricts water flow, causing the foliage to wilt and turn yellow. Symptoms appear later in the growing season and are first noticed on the lower (older) leaves. As the disease progresses, the younger leaves will also be affected (leaves start drooping, curve downwards and turn brown yellow) and the plant eventually dies (Figure 6) [4,34,64,77,92].

Wellman [93] described early symptom of tomato wilt and it is believed to be the first above-ground indication of infection of the tomato by wilt pathogen. Foster [94] reported that the early symptom is clearing of the ultimate veinlets in the leaflets of infected tomatoes giving them a netted appearance. Horsfall and Dimond [75] reported that tomato plants affected by F. oxysporum lycopersici show severe break down on vascular tissue only in the last stages of disease and then only if the plant is young (Figure 6b).

\section{Management of Fusarium wilt}

The control of Fusarium wilt of tomato is important in maintaining plant vigour and fruit quality and quantity $[62,77]$. Integrated disease management (IDM) is an approach used to maintain plant health by minimizing damage caused by diseases [95]. Control principles and methods of Fusarium wilts should be targeted to excluding the pathogen, as well as reducing the amount and/or efficiency of the initial inoculum. Therefore, IDM strategies include: (1) Use of pathogen-free planting material, (2) Site selection to avoid planting into high risk soils, (3) Reduction or elimination of $F$. oxysporum inoculum in soil, (4) Use of bio-control agents for protection of healthy planting material from infection by res- ident or incoming inoculum subsequent to planting, (5) Use of resistant cultivars regardless the level of resistance, and (6) Choice of cropping practices to avoid conditions favoring infection of the plant [96].

Pathogenic strains are characterized by their ability to invade and colonize the vascular system of the host plant. Integrated disease control methods can be applied by the application of biological, chemicals, cultural, physical, and regulatory methods, depending of the nature of the agents used [62].

Cultural practices were reported by different authors, Agrios [27] reported that seedbed sterilization and crop rotation has reduced infection by Fusarium. Jones and Overman [97] noticed that rotations of up to 5-7 years can significantly reduce soil inoculum levels. The type of soil has also affected reduction on inoculum potential of fungus. Jones and Overman [97], Walker [98] and Jones, et al. [99] showed that soil $\mathrm{pH}$ and fertility can also have significant effect on the severity of Fusarium wilt. Agrios [25] reported that the use of healthy seed and transplants is mandatory and hot-water treatment for seed should precede planting.

\section{Chemical Methods}

Soil treatment with broad-spectrum fumigants such as methyl bromide, chloropicrin, or methyl isothiocyanate successfully controlled Fusarium wilt of tomato and increased crop yield [11,12,22,32,33,62,100,101]. Anon [102] and Ristaino and Thomas [103] reported that methyl bromide fumigation is used for tomato production in some geographical areas. Biehne [104] found that benomyl applied to tomato plants 2 to 3 days after inoculation with Fusarium has reduced wilt symptoms approximately $70 \%$ in 2.5 to 3 weeks after inoculation.

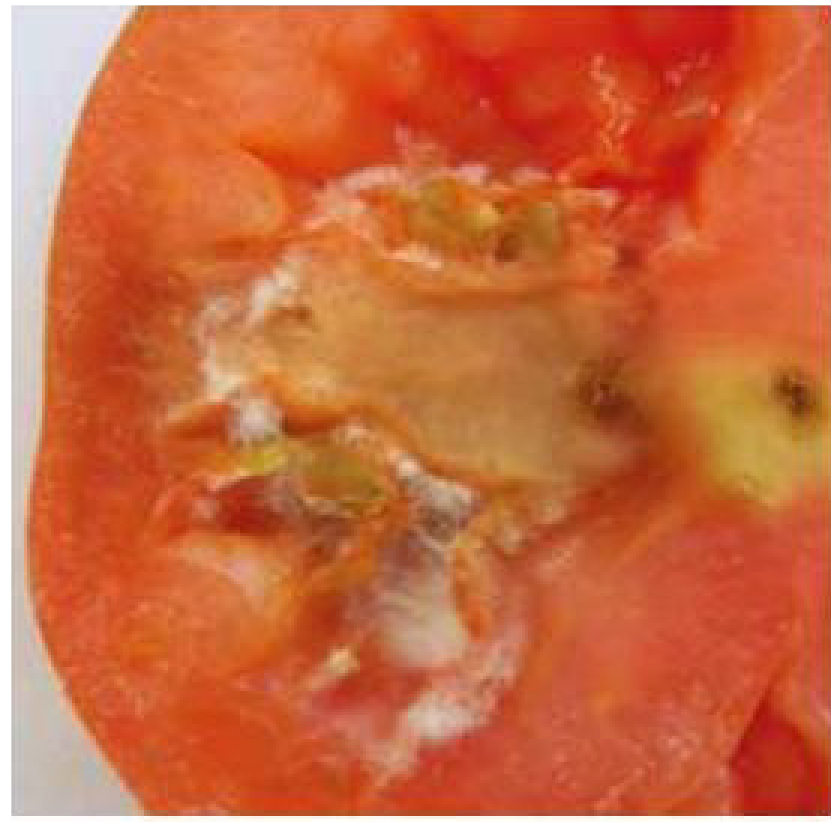

(a)

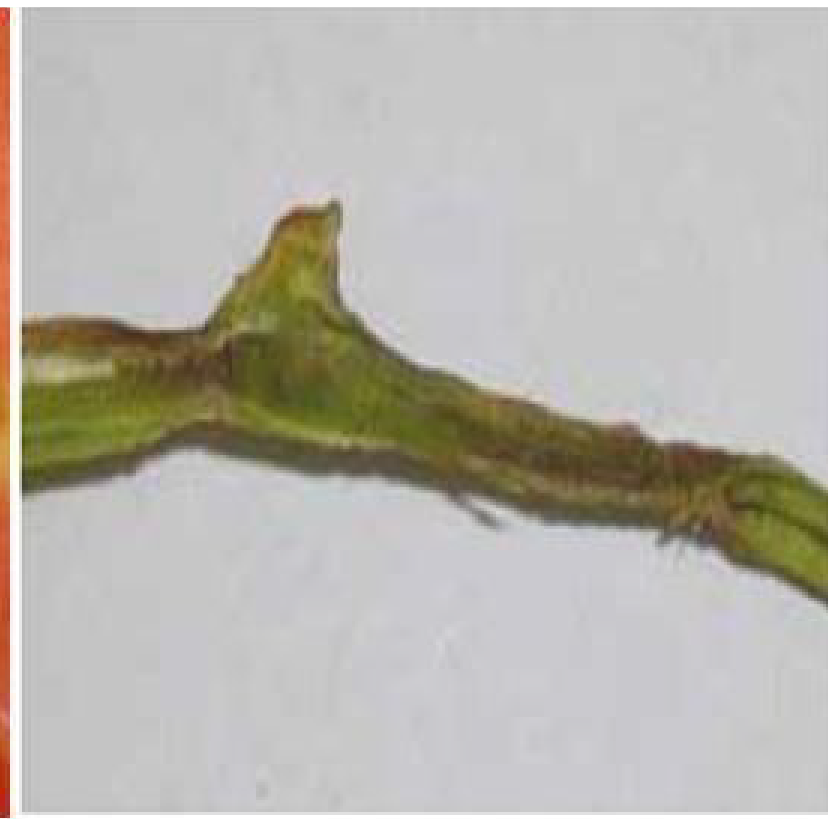

(b)

Figure 6: a) Tomato Fusarium rots symptoms; b) Vascular system browning of the stem [48]. 
Citation: Hassan HA (2020) Biology and Integrated Control of Tomato Wilt Caused by Fusarium oxysporum lycopersici: A Comprehensive Review under the Light of Recent Advancements. J Bot Res 3(1):84-99

Limiting the uptake of benomyl to 6 to 11 days before inoculation, however, resulted in only $7 \%$ reduction in disease symptoms. However, the efficiency of soil fumigation is affected by either survival of pathogens in soil layers below the depth of effective fumigation, or reintroduction of them through infected planting material or by conidia carried in the air or irrigation water [105]. Also, methyl isothiocyanate is used to enhance biodegradation in soil by adaptation of microbial populations to use the compound as an energy source [106].

Other chemical fungicides such as prochloraz and carbendazim [107], bavistin [108] and salicylic acid [109] are used to suppress the disease by inducing resistance, but these chemicals have a negative impact on human health and are hazardous to the environment. Pathogen resistance could emerge against these fungicides under certain circumstances. Moreover, the residual of many fungicides could damage the ecosystem and negatively affect human life if they reach our diet or water $[17,44,53,110]$.

\section{Physical Methods}

Soil solarization, flooding and sanitation are physical ways used for the control of Fusarium wilt diseases [32,62]. Soil solarization is a hydrothermal process that occurs when moist soil is covered with thin $(25$ to $50 \mu \mathrm{m})$, transparent plastic polyethylene or polyvinyl sheets during a period of high temperature and intense solar radiation [12,22,96]. It was used to reduce the population density of Fusarium species in soil by 88 to 93 , and provided effective control Fusarium wilt diseases on tomato [20]. Katan, et al. [111] noted that soil solarization for 2 weeks during summer time in Israel reduced the populations of buried inoculum of $F$. oxysporum vasinfectum and Verticillium dahliae by 94 to $100 \%$ at $5 \mathrm{~cm}, 67$ to $100 \%$ at $15 \mathrm{~cm}$, and 54 to $74 \%$ at $25 \mathrm{~cm}$. Effective disease control was obtained with maximum temperatures within the range of 45 to $50^{\circ} \mathrm{C}$ and 38 to $45^{\circ} \mathrm{C}$ at depths of 10 and $20 \mathrm{~cm}$ respectively [96]. Flooding is a soil disinfestation method which harms soil-borne pathogens by reduction of $\mathrm{O}_{2}$, increase of $\mathrm{CO}_{2}$, or a diversity of microbial interactions that result in toxic substances to pathogens upon anaerobic processes [95].

Sanitation includes practices that remove and destroy sources of inoculum from affected plants or infested debris. Thus, flaming residues of affected crops to achieve thermal killing of pathogen resting structures would reduce that effect and reduce disease risk in host crops. Flaming crop debris with propane or oil fuelled flamers allow more controlled heating similar to thermo-sanitation with lesser environmental effect $[32,96]$.

\section{Genetic Methods: Use of Resistant Cultivars}

The use of resistant cultivars is one of the most practical, cost-efficient, and environmentally safe control method for the management of Fusarium wilt diseases. However, several factors can limit its use and effectiveness, including genetic and pathogenic variability, and the evolutionary pattern of the pathogen, availability of resistance sources, and co-infection of the plant by other pathogens, genetics and penetrance of resistance $[11,22,62,77,96]$. The use of resistant varieties is an important method, which is reliable and cheap for management of plant disease but due to development of new races of the pathogen, the resistant variety becomes susceptible one $[12,17]$.

According to Pritesh, et al. [112], identification and utilization of tomato plant varieties resistant to the disease represents an alternative choice to the use of chemicals. The advantages of this method include saving the cost of chemical for control of the disease and enhancing cultivation of previously infested field. But, due to breakdown of resistance in the face of high pathogenic variability in the pathogen population, the usefulness of many resistant cultivars is restricted to only a few years $[113,114]$.

In Jordan, Al-Khatib, et al. [69] studied the local tomato cultivars resistance to Fusarium oxysporum lycopersici, Twenty-four cultivars were inoculated with composite samples of fungal suspensions from race 1 , race 2 , and equal volumes of race 1 and race 2 isolates of $F$. oxysporum lycopersici using the standard root dip method. The effect of tomato growth stage at the time of infection with the vascular wilt fungus F. oxysporum lycopersici was investigated. The age of tomato plant played an important role in its ability to overcome the disease, and there were significant differences among plants inoculated soon after transplanting, one, two, and three weeks after transplanting, compared to plants inoculated four weeks after transplanting which did not show any significant differences from the non-inoculated control under experimental conditions.

\section{Biological Control}

In an attempt to reduce the use of chemical pesticides, there is an increasing interest in introducing several biological control agents and plant compounds as natural commercial products for managing soilborne pathogens. It is generally ideal, safer and has a minimal environmental impact $[11,17,22,32,62,76]$.

Fuchs, et al. [115] reported that several biological control agents including bacteria and non-pathogenic strains of Fusarium oxysporum have shown promise for the control of Fusarium wilt of tomato. Different Trichoderma species are effective biological control agents against a range of crop diseases especially Fusarium wilt pathogen of tomato $[32,116,117]$. The capability of Trichoderma spp. to suppress plant diseases is due to their direct antagonistic effects on the fungal pathogen, and especially their ability to produce lytic enzymes e.g. chitinases and $\beta$-1, 3-glucanases [118,119]. These enzymes hydrolyze the pathogen's cell wall thereby limiting the growth of fungal pathogens [118].

Panteleev [120] reported that coating seed with culture of $T$. viridae lowered incidence of $F$. oxysporum lycopersici on tomato from 29.5 to 6-15\%. Gail, et al. [121] and Jayalakshmi, et al. [122] reported that the activity of both polyphenoloxidase and peroxidase increased after the treatment with $T$. harzianum, and also with El-Khallal [123]; Mandal, et al. [124], since they showed that the activity of POD was increased in response to foliar spray of salicylic acid. Spraying of salicylic acid increased the activity of the enzyme in Trichoderma seedling 
Citation: Hassan HA (2020) Biology and Integrated Control of Tomato Wilt Caused by Fusarium oxysporum lycopersici: A Comprehensive Review under the Light of Recent Advancements. J Bot Res 3(1):84-99

root dipping treatment not in soil applied treatment. Combination of salicylic acid and Trichoderma as seedling root dipping and thiophanate methyl with its half recommended rate recorded a higher PPO and POD activity.

Different bacteria were reported as they capable to control various plant diseases $[32,118,125]$. Pathogen suppression methods by the antagonistic bacteria include direct parasitism, antibiotic production, and substrate competition and induced systemic resistance in the plant host $[126,127]$. The cell wall-degrading enzymes, as chitinases, glucanases, and proteases are the major lytic enzymes that are secreted by different biocontrol agents [128]. These enzymes attack the cell walls of phytopathogenic fungi, causing cell lysis and ends with death $[129,130]$. Moreover, the production of volatile antimicrobial compounds by the antagonistic bacteria and fungi has been well reported [131].

Cruz-Rodríguez, et al. [55] studied The C. longirostrata branch extract efficacy for the control of Fusarium wilt in maize. The application of the extract reduced the percentage of disease incidence significantly caused by Fusarium verticillioides from $70.4 \%$ to $40.12 \%$ as compared to non-treated plants, and the disease severity was reduced from $40.15 \%$ to $29.46 \%$.

Plant extracts and plant essential oils have been reported to be effective antimicrobials against food and grain storage fungi, foliar pathogens and soilborne pathogens $[23,34,76,132]$. These are good alternatives to chemical pesticides, as they are readily biodegradable in nature $[4,23,62]$.

Garlic (Allium sativum) is a popular spice, is also known for its medicinal uses as an antibiotic, anti-thrombotic and antineoplastic agent. Garlic contains at least thirty-three sulfur compounds, several enzymes and seventeen amino acids. Additional ingredients of intact garlic include steroidal glycosides and lectins [132].

Activity of garlic extract toward fusarium wilt is due to sulfur-containing compounds such as ajoene or allicin. Sprays with aqueous garlic extract have antibiotic and antifungal properties and will suppress a number of plant diseases, including powdery mildew on cucumbers and, to some extent, black spot on roses. Garlic extract controlled diseases such as mildew, rusts, fruit rots, blights, and black spot $[62,132]$. Garlic releases fungicidal chemicals into the soil. Its extract shows high inhibitory activity against Aspergillus niger, Penicillium cyclopium and $F$. oxysporum for all tested concentrations. Allicin is the active antimicrobial component of garlic extract; it is a natural product used to treat several plant pathogens [54]. Allicin is known as 2-propene-1-sulfinothioc acid S-2-propenyl ester; thio-2-propene-1-sulfinic acid S-alIyl ester. Obagwu and Korsten [133] noticed that using garlic extract was an effective method to control green and blue molds of citrus caused by Penicillium digitatum and $P$. italicum and they found that garlic extract can inhibit growth and development of mycelia for both pathogens significantly.

Coventry, et al. [134] reported that neem (Azadirachta indica) extract showed antimicrobial activity with recorded effects on some fungal pathogens. Kimaru, et al. [135] revealed that neem cake powder contains ingredients that have fungistatic effects against Fusarium wilt of tomatoes. Agbenin and Marley [136] reported that crude extracts of neem and garlic at concentrations ranging from $5 \%$ to $30 \%$ of the material in $100 \mathrm{ml}$ of potato Dextrose Agar inhibited mycelial growth of F. oxysporum lycopersici at various levels. Dry neem seed extract gave $100 \%$ inhibition. In a study of Agbenin and Marley [136], they reported the effect of different extracts of neem leaf, neem seed and garlic at concentrations ranging from $5 \%$ to $30 \%$ of the material in $100 \mathrm{ml}$ of Potato Dextrose Agar on mycelial growth of $F$. oxysporum lycopersici.

All the extracts inhibited mycelial growth at various levels. Dry neem seed extract inhibited mycelial growth $100 \%$. Fresh neem leaf extract reduced mycelial growth with increasing concentration while in garlic there were no differences in growth inhibition among the various concentrations used. However garlic extracts decreased sporulation with increasing concentration and cultures grown on extract amended agar plates.

Hanaa, et al. [137] investigated the effect of neem and willow (Salix babylonica) 10\% aqueous extracts on Fusarium wilt disease in tomato and revealed that the percentage of disease incidence was reduced to the level of $25.5 \%$ and $27.8 \%$ after 6 weeks of infection. Also, fresh neem leaf extract reduced mycelial growth with increasing concentration while in garlic; there was no difference in growth inhibition among the various concentrations used.

In the study of Jun Ma, et al. [138], garlic and black pepper extracts each at $0.5 \%$ and $4 \%$ concentrations were used as natural resistance inducer treatments for treating 4-weeksold tomato seedlings. The highest concentration (4\%) of garlic and black pepper was significantly better than the lowest concentration $(0.5 \%)$ for reducing the percentage of wilted plants and wilt disease severity comparing to the untreated inoculated control.

Mishra, et al. [20] noted that the extract of goat weed (Ageratum conyzoides) exhibited maximum toxicity (96\%) against $F$. oxysporum lycopersici. Significant results were also observed with extracts of floss flower (Ageratum houstonianum), glory bower (Volkameria inermis) and beleric (Terminalia bellirica) showing inhibition of $90 \%, 85 \%$ and $79 \%$, respectively.

Yeole, et al. [23] screened seven plant extracts against F. oxysporum; cinnamon (Cinnamomum zeylanicum); hing (Ferula foetida); anantmul (Hemidesmus indicus); pushkarmool (Inula racemosa); manjishtha (Rubia cordifolia); kushta (Saussurea lappa) and clove (Syzygium aromaticum). Methanol (MeOH) extract of clove showed largest zone of inhibition; solvent extracts of cinnamon and clove exhibited $100 \%$ inhibition of $F$. oxysporum spores at 5 and $10 \mathrm{~mL} . \mathrm{L}^{-1}$ concentration. The active compounds (metabolites) in the methanolic clove extracts were separated and identified as eugenol and 1-heptatriacotanol.

Earlier studies reported that eugenol inactivate several enzymes, cell membrane integrity and affect genetic material [139]. Also, being a lipophilic compound, eugenol can enter 
Citation: Hassan HA (2020) Biology and Integrated Control of Tomato Wilt Caused by Fusarium oxysporum lycopersici: A Comprehensive Review under the Light of Recent Advancements. J Bot Res 3(1):84-99

the fatty acid chains in the membrane lipid bilayer and alter fluidity and permeability of cell membranes [140]. Akaeze, et al. [49] reported that methanol extracts of $A$. indica at low concentration of $12.5 \%$ showed more bioactivity against $F$. oxysporum lycopersici.

Ohunakin and Bolanle [141] evaluated aqueous extracts of garlic, ginger (Zingiber officinale) and wormseed (Dysphania ambrosioides) against $F$. oxysporum. A. sativum at $100 \%$ gave the highest inhibitory effect $(71.24 \%)$ on mycelial growth, and compete with carbendazim (80.38\%). Hot water extraction revealed better antifungal effects (45.86\%) on F. oxysporium than cold water extract (33.80\%). A. sativum showed the highest inhibition of $71.24 \%$ and $66.92 \%$ at $80 \%$ and $100 \%$ respectively, after carbendazim (80.38\%) at 0.5 $\mathrm{mg} / \mathrm{ml}$ which is the standard. However, all extracts recorded the lowest mycelia growth at $20 \%$ concentration level.

Sreenu and Zacharia [142] investigated the antifungal activity of aqueous extract of neem leaf (5\%), ginger bulb (5\%), West Indian lantana (Lantana camara) (5\%), Trichoderma harzianum $(5 \%)$, carbendazim $(0.01 \%)$ and combination of carbendazim $+\mathrm{T}$. harzianum $(0.01+5 \%)$ against $F$. oxysporum lycopersici in vitro. The least growth of pathogen was recorded in carbendazim (treated control) followed by neem leaf followed by Lantana camara ginger bulb and there was no growth in carbendazim treatment in poison food technique.

Nasrin, et al. [34] studied biological and chemical control of Fusarium oxysporum lycopersici by nine plant extracts, three fungicides (Sulcox, Indofil M 45 and Ridomil MZ 68) and three antagonistic fungi. They reported that all plant extracts at $25 \%$ concentration were effective in reducing the mycelium growth of Fusarium oxysporum lycopersici. Antagonistic effect of Trichoderma sp. shows the highest percent inhibition radial growth (82\%) as compared to Sclerotium sp. and Aspergillus sp. against Fusarium oxysporum lycopersici. Chemical treatment with Sulcox was proved that the most effective fungicides against this pathogen.

Plant essential oils are concentrated volatile hydrophobic liquids extracted from different parts of the characteristics according to the identification keys of aromatic plants [143]. Clove oil has been known as organic pesticide derived from different parts of the clove plant [144]. It has useful antimicrobial effects on different plant pathogens as fungi, bacteria and nematodes [62,145]. Thabet and Khalifa [145] investigated the inhibitory effects of different concentrations of clove oil on the mycelial growth and spore germination of all isolated fungi. Clove oil exhibited an inhibitory effect against the mycelial growth of all pathogens. All tested concentrations reduced mycelial linear growth of the tested fungi compared to respective controls significantly. Complete growth inhibition was observed in F. oxysporum and Rhizoctonia solani when clove oil was applied at concentration of $4 \%$.

The phyto-constituents obtained from piper species are characterized by the production of typical classes of compounds such as amides, benzoic acids, chromenes, terpenes, phenylpropanoids, lignans, other phenolics and a series of alkaloids. They have shown anti-feeding, antibacterial, antifungal, antiplatelet, antioxidant, anti-inflammatory, antiamoe- bic, insecticidal, cytotoxic, antiplasmodial and DNA damaging activities [146]. P. nigrum, known as black-pepper, has shown great potential for the discovery of novel biologically active compounds and need for techniques to enhance the production of high quality consistent plant material for accumulation of metabolites [147].

Effectiveness of crude chloroform extract of betel (Piper betle) in controlling Fusarium wilt of tomato was observed by Singha, et al. [12]. It was observed that $1 \%(w / w)$ amendment of the crude chloroform extract of Piper betle $L$. $(\mathrm{PbC})$ in soil was more efficient in reducing the Fusarium population in soil than carbendazim and the combined amendment of carbendazim and chloroform extract of Piper betle $L(\mathrm{PbC})$. Higher accumulation of total phenolics was observed in the Fusarium-infested plants as compared to that of healthy control and PbC-treated plants. Moreover, it was observed that the extract could reduce the symptoms and disease development.

In Jordan, Sidawi, et al. [148] evaluated the efficiency of methanolic extracts of the following plants: fig (Ficus carica) leaves, myrtle (Myrtus communis) leaves, and stem, leaves, flowers and roots of marigold plant (Tagetes patula) separately to control Fusarium wilt and root rot disease on tomato plants. They concluded that both extracts of marigold stem and leaves with $6 \%$ concentration significantly reduced the percent of infected plants. In another study, Al-Hussaen, et al. [44] recommended the use of garlic plant extracts to control Pythium ultimum on tomato seedlings since it is considered as an environmentally friendly product. Undiluted garlic extract showed the highest control activity with no growth as compared to the biotic control without the extract whereas diluted garlic extracts 10 and $5 \%$ reduced the fungal growth to 15.5 and $41 \%$, respectively.

Several studies report that soil amendments with composts control several important soil-borne pathogens including Fusarium wilts [101]. These composts suppress plant diseases through biotic and abiotic factors that reduce disease severity [149]. Populations of non-pathogenic strains of Fusarium oxysporum and fluorescent Pseudomonas spp. were shown to be contributed in the supressivness process toward fusarium wilt [101]. Abiotic proprieties, such as the nature of any clays and $\mathrm{pH}$, interact with these microbial populations that support supressiveness effect $[67,149]$.

Ros, et al. [101] assayed the biopesticide effect of four green composts against fusarium wilt in melon plants and the effect of soil quality in soils amended with composts. Green composts showed high advantageous characteristics; improved plant growth and controlled fusarium wilt in melon plants.

Al-Hussain, et al. [150] concluded that combinations of bio-control agents and resistance inducer could provide promising integrated alternatives in suppression of Fusarium wilt disease of tomato plants due to number of mechanisms involved. Naing, et al. [151] concluded that bacterial strain Paenibacillus ehimensis KWN38 showed high antifungal activity against six tested fungal pathogens belonging to various taxonomic groups; the strain produced volatile antimicrobial 
Citation: Hassan HA (2020) Biology and Integrated Control of Tomato Wilt Caused by Fusarium oxysporum lycopersici: A Comprehensive Review under the Light of Recent Advancements. J Bot Res 3(1):84-99

compounds which had strong fungal growth inhibitory effect. The strain also showed high chitinase, cellulase, glucanase and protease activities.

Kouki, et al. [152] investigated the efficiency of both compost of vegetable waste and Posidonia oceanica mixture (70:30\% v:v) against $F$. oxysporum radicis-lycopersici, The incorporation of non-sterilized vegetable posidonia oceanica compost (VPC) in the culture medium showed potent antifungal activity against $F$. oxysporum and complete inhibition of mycelium growth was observed for all the tested compost rates $(0.5,1,2,4,6,8,10,15$ and 20\%). Bacillus sphaericus (B12 and BS2), Pseudomonas putida PPS7 and Burkholderia gladioli BuC16 bacterial strains protected significantly tomato against F.oxysporum radicis-lycopersici attacks.

Salem, et al. [149] also evaluated the compost effectiveness on Zea mays and Hibiscus sabdarriffa under Fusarium wilt disease. A significant decrease was observed for both Z. mays and $H$. sabdarriffa compared to infected plants without compost. The observed disease suppression in compost-amended soil was associated with the reduction in soil pathogen population and increase in microbial activity of composts. Moreover, diversification of different organic materials in compost enhanced the activation of the microbial population in soil that eventually increases disease supressiveness and effectively controlling Fusarium wilt.

In another study of Hasan and Abo-elyousr [153] suppressive effects of six compost types on Fusarium wilt disease were studied under greenhouse conditions. Soil treatments with Khaya and Eucalyptus composts significantly reduced the infection percentage and disease severity of basil wilt. Otherwise, the applications of Araucaria, Datura, Ficus and Azadirachta composts showed no effect on both infection percentage and disease severity.

Juber, et al. [31] evaluated the efficiency of biocontrol agents (Bacillus mycoides and Trichoderma viride) and the chemical compounds, Acibenzolar-S-methyl (ASM) and Preservepro against F.oxysporum lycopersci in culture media and under greenhouse conditions. The results showed that all the control agents exhibited an inhibition rate on $F$. oxysporum growth on both culture media and under natural conditions. The addition of bio- and chemical agents to the contaminated soil induced significant reduction in disease incidence and disease severity associated with increase plant dry weight.

Markakis, et al. [67] assayed the suppressive effect of six different compost amendments (A, B, C, D, E and Z) against Fusarium oxysporum radicis-cucumerinum (Forc) in cucumber and Verticillium dahliae in eggplant. It was shown that composts $A, B, C$ and $D$ were effective against Forc, and composts $C$, Dand $Z$ were effective against $V$. dahliae. The decreased symptom severity and $V$. dahliae isolation ratio in eggplant was associated with significantly lower accumulation of phenols in stem tissues; whereas the concentration of total phenols in stem tissues of $V$. dahliae-infested eggplants was significantly higher compared to the non-infested.

Cruz-Rodríguez, et al. [55] evaluated the C. longirostrata branch extract for the control of Fusarium wilt in maize. The application of the extract reduced the percentage of disease incidence caused by Fusarium verticillioides from $70.4 \%$ to $40.12 \%$ as compared to non-treated plants, by which, disease severity was reduced from $40.15 \%$ to $29.46 \%$. The phytochemical components of the extract were cinnamic acids (caeic acid and ferulic acid) and phenolic acid (gall acid).

\section{Conclusion}

Effective disease management is best achieved by quick diagnosis and practicing integrated disease management strategies. Use of pathogen free seed of wilt resistant cultivars is most successful, practical and cost efficient measure for disease management. Moreover, additional work for discovering of genetics and host-pathogen interaction are needed to produce high yielding wilt resistant cultivars. Combined use of wilt resistant cultivars delayed planting, seed dressing with fungicides, avoidance from dense planting, and use of bio-control agents) help in reduction of disease incidence.

\section{Acknowledgment}

The author would like to thank Pr. Dr. Ivan Sache, AgroParisTech, France, for work's guidance and manuscript's proof-reading, also thank to Pr. Dr. Ahmad Almomany. The University of Jordan, Amman, Jordan for work's guidance.

\section{References}

1. Joshi M, Srivastava R, Sharma AK, et al. (2013) Isolation and characterization of Fusarium oxysporum, a wilt causing fungus, for its pathogenic and non-pathogenic nature in tomato (Solanum lycopersicum). ANSF 5: 108-117.

2. Amer MA, El-Samra A, Abou-El-Seoud I, et al. (2014) Induced systemic resistance in tomato plants against fusarium wilt disease using biotic inducers. Middle East Journal of Agriculture Researc 3: $1090-1103$

3. Lengai GM, Muthomi JW, Narla RD (2017) Efficacy of plant extracts and antagonistic fungi in managing tomato pests and diseases under field conditions. Journal of Agriculture and Life Sciences 4: 2375-4222.

4. Worku M, Sahela S (2018) Review on disease management practice of tomato wilt caused by Fusarium oxysporum in case of Ethiopia. Journal of Plant Pathology and Microbiology 9.

5. Mahalakshmi G, Vengadeshkumar L, Rajamohan K, et al. (2020) Leaf extract of Rhizophora apiculata as a potential bio-inducer of early blight disease resistance in tomato plant. Novel Research in Microbiology Journal 4: 714-724.

6. Benton J (2007) Tomato plant culture: In the field, greenhouse, and home garden. CRC Press, London.

7. Hedrick UP (1919) Strutevant Notes on Edible Plants. JB, Lyon Co, Albany.

8. Rick CM (1976) Tomato. In: NW Simmonds, Evolution of crop plants. (edn), Longman, London.

9. Arnó J, Gabarra R, Estopà M, et al. (2008) Evaluation of tools to manage whiteflies in European tomato crops - The tomato case study. Agritrop.

10. Al-Shadiadeh A, Al-Mohammady FM, Abu-Zahrah TR (2012) Factors influencing adoption of protected tomato farming practices among farmers in Jordan Valley. World Applied Sciences Journal 17: $572-578$. 
Citation: Hassan HA (2020) Biology and Integrated Control of Tomato Wilt Caused by Fusarium oxysporum lycopersici: A Comprehensive Review under the Light of Recent Advancements. J Bot Res 3(1):84-99

11. Poussio GB, Abro MA, Hajano BA, et al. (2018) Potential of plant extracts and fungicides for managing fusarium oxysporum $\mathrm{f} . \mathrm{sp}$ Lycopersici. Pakistan Journal of Phytopathology 30: 75-81.

12. Singh R, Biswas SK, Nagar D, et al. (2015) Sustainable integrated approach for management of Fusarium wilt of tomato caused by Fusarium oxysporum f. sp. Iycopersici (Sacc.) Snyder and Hansen. Sustainable Agriculture Research 4: 138-147.

13. Hassanein NM, Mohamed Abou-Zeid MA, Youssef KA, et al. (2010) Control of tomato early blight and wilt using aqueous extract of neem leaves. Phytopathology 49: 143-151.

14. FAO (2009) Statistical Bulletin, Rome, Italy 150: 1-2.

15. Hussain I, Alam S, Khan I, et al. (2016) Study on the biological control of fusarium wilt of tomato. Journal of Entomology and Zoology Studies 4: 525-528.

16. (2018) Department of statistics, Ministry of Agriculture, Jordan.

17. Sadana D, Didwania N (2019) Integrated disease management of bull's eye pathogen infecting lycopersicon esculentum (Tomato). Journal of Microbiology, Biotechnology and Food Sciences 9: 53-57.

18. Wiam B, Wassima L, Abderrahmene D, et al. (2019) Experimental approach for easy identify Fusarium wilt of tomato. World Journal of Environmental Biosciences 8: 44-48.

19. Singha IM, Kakoty Y, Unni BG, et al. (2011) Control of Fusarium wilt of tomato caused by Fusarium oxysporum f. sp. lycopersici using leaf extract of Piper betle L.: A preliminary study. World Journal of Microbiology and Biotechnology 27: 2583-2589.

20. Mishra P, Singh P, Tripathi NN (2014) Evaluation of plant extracts against Fusarium oxysporium sp. lycopersici, wilt pathogen of tomato. International Journal of Food, Agriculture and Veterinary Sciences 4: 163-167.

21. Nazim MN, MA Awad MA, Basiony AA (2015) Biological control of root-rot disease on tomato. Menoufia Journal of Agriculture Research 40: 359-372.

22. Adedeji KO, Aduramigba Modupe AO (2016) In vitro evaluation of spent mushroom compost on growth of Fusarium Oxysporium F. Sp Lycopersici. Advances in Plants \& Agriculture Research 4.

23. Yeole GJ, Kotkar HM, Teli NP, et al. (2016) Herbal fungicide to control Fusarium wilt in tomato plants. Biopesticide International 12: 25-35.

24. Carmona SL, Burbano-David D, R Gómez M, et al. (2020) Characterization of pathogenic and nonpathogenic Fusarium oxysporum isolates associated with commercial tomato crops in the Andean region of Colombia. Pathogens 9: 70.

25. Agrios GN (1997) Plant pathology. ( $4^{\text {th }}$ edn), Academic Pressinc, New York.

26. Abdel-Monaim MF (2012) Induced systemic resistance in tomato plants against Fusarium wilts disease. International Research Journal of Microbiology 3: 14-23.

27. Amini M, Safai N, Salmani MJ, et al. (2012) Antifungal activity of three medicinal plant essential oils against some phytopathogenic fungi. Trakia Journal of Sciences 10: 1-8.

28. Khurshid S, Shoaib A, Javaid A, et al. (2016) Fungicidal potential of allelopathic weed Cenchrus pennisetiformis on growth of Fusarium oxysporum lycopersici under chromium stress. Planta Daninha 34: 453-463.

29. Hatem MW, Shukri HM, Rasheed KA, et al. (2020) The effect of magnetically treated water against Fusarium wilt disease in tomato caused by the fungus Fusarium oxysporum and its effect on production under fertilized farming conditions. Plant Archives 20: 533-536.

30. Jacobs A, Govender R, van Heerden SW (2013) Fusarium oxysporum f. sp. lycopersici race 3 causing tomato wilt in South Africa. Australasian Plant Disease Notes 8: 145-147.

31. Juber KS, Hassan AK, Alhamiri YN (2014) Evaluation of biocontrol agents and chemical inducers for managing vascular wilt of tomato caused by Fusarium oxysporum f.sp.lycopersici. Journal of Biology, Agriculture and Healthcare 4: 335-343.

32. Mihajlović M, Rekanović E, Jovana Hrustić J, et al. (2017) Methods for management of soil borne plant pathogens. Journal Pesticides and Phytomedicine 32: 9-24.

33. Bowers HJ, Locke JC (2004) Effect of formulated plant extracts and oil on population density of Phytophthora blight in the greenhouse. Plant Disease 88: 11-16.

34. Nasrin L, Podder P, Mahmud MR (2018) Investigation of potential biological control of Fusarium Oxysporum f.sp. Lycopersici by plant extracts, antagonistic $\mathrm{sp}$. and chemical elicitors in vitro. Fungal Genomics and Biology 8: 155.

35. Njiru MD (2012) Integrated management of Fusarium wilt of tomatoes using fungicides, organic matter and neem extract. Ph.D. Thesis. School of Pure and Applied Sciences, Kenyatta University, Kenya.

36. Mng'omba SA, Sileshi G, Du Toit ES, et al. (2012) Efficacy and utilization of fungicides and other antibiotics for aseptic plant cultures. In: D Dhanasekaran, Fungicides for Plant and Animal Diseases. InTech Publisher, Rijeka, Croatia, 245-254.

37. Jones JP, Jones JB, Miller W (1982) Fusarium wilt on tomato. Plant Pathology Circular No. 237, Florida Department of Agriculture and Consumer Services, Division of Plant Industry.

38. Agrios GN (1988) Plant pathology. ( $3^{\text {rd }}$ edn), Academic Press, Inc., New York.

39. Nam CG, Jee HJ, Kim CH (1988) Studies on biological control of Phytophthora blight of red pepper. Korean Journal of Plant Pathology 4: 313-318.

40. Alabouvette C (1999) Fusarium wilt suppressive soils: An example of disease suppressive soils. Australian Plant Pathology 28: 57-64.

41. Van Dam B, de Goffau M, van Lidth de Jeude J, et al. (2005) Cultivation of tomato: Production, processing and marketing. Agrodok; 17. Agromisa/CTA, Wageningen, The Netherlands.

42. ILO (2014) Market Study and marketing strategy of tomato sector in Mafraq. Draft Report v2.

43. Department of Statistics, Agricultural Survey (2012) Jordan.

44. Al-Hussaen K, Hussein El, Al-Batayneh KM, et al. (2011) Identification and controlling Pythium sp. infecting tomato seedlings cultivated in Jordan Valley using garlic extract. Asian Journal of Plant Pathology 5: 84-92.

45. Watt BK, Merril AL (1963) Composition of Food. U.S Dept. Agric. Handbook No. 8, 190.

46. Nicola S, Tibaldi G, Fontana E (2009) Tomato production systems and their application to the tropics. Acta Horticulturae 821: 2734 .

47. Arzoo K, Biswas SK, Rajik M (2012) Biochemical evidences of defence response in tomato against Fusarium wilt induced by plant extracts. Plant Pathology Journal 11: 42-50. 
Citation: Hassan HA (2020) Biology and Integrated Control of Tomato Wilt Caused by Fusarium oxysporum lycopersici: A Comprehensive Review under the Light of Recent Advancements. J Bot Res 3(1):84-99

48. Ignjatov M, Milošević D, Nikolić Z, et al. (2012) Fusarium oxysporum as causal agent of tomato wilt and fruit rot. Pestic Phytomed (Belgrade) 27: 25-31.

49. Akaeze O, Aduramigba-Modupe A (2017) Fusarium wilt disease of tomato: Screening for resistance and in-vitro evaluation of botanicals for control; the Nigeria case. Journal of Microbiology, Biotechnology and Food Sciences 7: 32-36.

50. Basco MJ, Bisen K, Keswani C, et al. (2017) Biological management of Fusarium wilt of tomato using biofortified vermicompost. Mycosphere 8: 467-483.

51. Burgess LW, Summerell BA, Bullock S, et al. (1994) Laboratory manual for fusarium research. ( $3^{\text {rd }}$ edn), University of Sydney Australia.

52. Chimbekujwo IB (2000) Frequency and pathogenicity of fusarium wilts (Fusarium solani and Fusarium equiseti) of cotton (Gossypium hirsutum) in Adamawa, Nigeria. Revista de Biología Tropical 48: 1-5.

53. Okungbowa FI, Shittu HO (2012) Fusarium wilts: An overview. Environmental Research Journal 6: 83-102.

54. Rana A, Sahgal M, Johri BN (2017) Fusarium oxysporum: Genomics, diversity and plant-host interaction. In: Tulasi Satyanarayana, Sunil K Deshmukh, BN Johri, Developments in Fungal Biology and Applied Mycology. Springer, 159-199.

55. Cruz-Rodríguez RI, Cruz-Salomón A, Ruiz-Lau N, et al. (2020) Potential application of crotalaria longirostrata branch extract to reduce the severity of disease caused by Fusarium. Agronomy 10: 524 .

56. Hennequin C, Abachin E, Symoens F, et al. (1999) Identification of Fusarium species involved in human infections by $28 \mathrm{~S}$ rRNA gene sequencing. J Clin Microbiol 37: 3586-3589.

57. Lacmanova I, Pazlarova J, Kostelanska M, et al. (2009) PCR-based identification of toxigenic Fusarium species. Czech J. Food Sci 27: 90-94.

58. Windles CE (1992) Fusarium. In: Singleton LL, Mihail JD, Ruch $\mathrm{CM}$, Methods for research on soil-borne phytopathogenic fungi. American Phytopathological Society Press, St. Paul MN, USA, 115-128.

59. Larone DH (1995) Medically important fungi - a guide to identification. ( $3^{\text {rd }}$ edn), ASM Press, Washington, USA.

60. Mui-Yun W (2003) Fusarium oxysporum f. sp. lycopersici (Sacc.): PP728 Soil-borne Plant Pathogen Class Project. North Carolina State University.

61. Armstrong GM, Armstrong JK (1981) Formae speciales and races of fusarium oxysporum causing wilt disease. In Fusarium: Disease, biology, and taxonomy.

62. Muhammad Rafiq $\mathrm{CH}$, Mahmood MT, Mushtaq Ahmad M, et al. (2020) Fusarium wilt's pathogenic studies and disease management: A review. Genetics and Molecular Research 19: gmr16039974.

63. Nelson PE, Toussoun TA, Marases W (1983) Fusarium species: An illustrate manual for identification.

64. Srinivas C, Nirmala D, Narasimha Murthy D, et al. (2019) Fusarium oxysporum f. sp. lycopersici causal agent of vascular wilt disease of tomato: Biology to diversity - A review. Saudi Journal of Biological Sciences 26: 1315-1324.

65. Ortoneda M, Guarro J, Madrid MP, et al. (2004) Fusarium oxysporum as a multihost model for the genetic dissection of fungal virulence in plants and mammals. Infect Immun 72: 1760-1766.
66. Lievens B, Houterman PM, Rep M (2009) Effector gene screening allows unambiguous identification of fusarium oxysporum $\mathrm{f}$. $\mathrm{sp}$. lycopersici races and discrimination from other formae speciales. FEMS Microbiology Letters 300: 201-215.

67. Markakis EA, Fountoulakis MS, Daskalakis GC, et al. (2018) The suppressive effect of compost amendments on Fusarium 1 oxysporum f.sp. 2 radicis-cucumerinum in cucumber and verticillium dahliae in eggplant. Crop Protection.

68. Elias KS, Schneider RW (1992) Genetic diversity within and among vegetative compatibility groups of fusarium oxysporum f. sp. Iycopersici as determined by isozyme analysis. Phytopathology 82: 1421-1427.

69. Al-Khatib M, Abu-Blan H, Masoud S (2006) Determination of resistance of locally grown tomato varieties to fusarium oxysporum $\mathrm{f}$. sp. lycopersici in Jordan under greenhouse conditions. Jordan Journal of Agricultural Sciences 2: 251-255.

70. Al-Khatib M, Brake M, Qaryouti M, et al. (2012) Response of jordanian tomato land races to fusarium oxysporum f.sp. Iycopersici. Asian Journal of Plant Pathology 6: 75-80.

71. Gäumann E (1958) The mechanisms of fusaric acid injury. Phytopathology 48: 670-686.

72. Dimond AE (1955) Pathogenesis in the wilt disease. Annual Reviews of Plant Physiology 6: 329-350.

73. Gothoskar S, Scheffer JC, Walker Stahmann MA (1955) The role of enzymes in the development of fusarium wilts of tomato. Phytopathology 45: 381-387.

74. Chambers HL, Corden MA (1963) Semeiography of fusarium wilts of tomato. Phytopathology 53: 1006-1010.

75. Horsfall JG, Dimond AE (1959) Plant Pathology. Academic Press, 1.

76. Bowers JH, Locke JC (2000) Effect of botanical extracts on the population density of fusarium oxysporum in soil and control of fusarium wilt in the greenhouse. Plant Dis 84: 300-305.

77. Bawa I (2016) Management strategies of fusarium wilt disease of tomato incited by fusarium oxysporum $\mathrm{f}$. $\mathrm{sp}$. lycopersici (Sacc.): A review. International Journal of Advanced Academic Research 2.

78. Stover RH (1962) Fusarial wilt (Panama disease) of bananas and other Musa species.

79. Stover RH (1962) Studies on fusarium wilt of bananas. ix. competitive saprophytic ability of $f$. oxysporum f.sp. cubense. Canadian Journal of Botany 40: 1473-1481.

80. Beckman CH, Roberts EM (1995) On the nature and genetic basis for resistance and tolerance of fungal wilt diseases. Advances in Botanical Research 21: 35-77.

81. Stover RH (1970) Banana root diseases caused by fusarium oxysporum f.sp. cubense, pseudomonas solanacearum, and radopholus similis: A comparative study of life cycles in relation to control. In root diseases and soil-borne pathogens. Int. Symp. on factors determining the behavior of plant pathogens in soil.

82. Bishop CD, Cooper RM (1983) An ultra-structural study of root invasion of three vascular wilt diseases. Physiological Molecular Plant Pathology 22: 15-27.

83. Lucas JA (1998) Plant pathology and plant pathogens. ( $3^{\text {rd }}$ edn).

84. Bishop CD, Cooper RM (1983) An ultrastructural study of root invasion in three vascular wilt diseases 1.Colonization of susceptible cultivars. Physiological Plant Pathology 23: 323-343. 
Citation: Hassan HA (2020) Biology and Integrated Control of Tomato Wilt Caused by Fusarium oxysporum lycopersici: A Comprehensive Review under the Light of Recent Advancements. J Bot Res 3(1):84-99

85. Indurm A, Howlett BJ (2001) Pathogenicity genes of phytopathogenic fungi. Molecular Plant Pathology 2: 241-255.

86. Manikandan R, Harish S, Karthikeyan G, et al. (2018) Comparative proteomic analysis of different isolates of Fusarium oxysporum f.sp. lycopersici to to exploit the differentially expressed proteins responsible for virulence on tomato plants. Front Microbiol 9: 420.

87. Wilson IM (1946) Observations on wilt disease in flax. Transactions of the British Mycological Society 29: 221-231.

88. Woltz SS, Jones JP (1981) Nutritional requirements of Fusarium oxysporum: Basis for a disease control system. In: PE Nelson, TA Toussoun, RJ Cook, Fusarium: Diseases, Biology and Taxonomy, Penn State Univ Press, University Park, London, 340-349.

89. Steinberg RA (1950) Growth on synthetic nutrient solutions of some fungi pathogenic to tobacco. American Journal of Botany 37: 711-714.

90. Woltz SS, Jones JP (1973) Interactions in source of nitrogen fertilizer and liming procedure in the control of Fusarium wilt of tomato. Hortscience 8: 137-138.

91. Rania AB, Rania AB, Hayfa JK, et al. (2018) Tomato-associated endophytic bacteria with Fusarium wilt suppression and tomato growth promotion abilities. Journal of Agricultural Science and Food Research 9: 4.

92. Nelson PE, Dignani MC, Anaisse EJ (1994) Taxonomy, biology, and clinical aspects of Fusarium species. Clinical Microbiology Reviews 7: 479-504.

93. Wellman FL, Blaisdell DL (1941) Pathogenic and cultural variation among single spore isolates from strains of the tomato wilt Fusarium. Phytopathology 103-120.

94. Foster RE (1946) The first symptoms of tomato Fusarium wilt: Clearing ofthe ultimate veinlets in the leaf. Phytophatology 36 : 961.

95. Kogan M (1999) Integrated pest management Constructive criticism or revisionism. Phytoparasitica 27: 93-96.

96. Jiménez-Díaz RM, Jiménez-Gasco MD (2011) Integrated management of Fusarium wilt diseases. Transworld Research Network.

97. Jones JP, Overman AJ (1971) Control of Fusarium wilt of tomato with lime and fumigants. Phytopathology 61: 1415-1471.

98. Walker JC (1971) Fusarium wilt of tomato. Monograph No. 6. St. Paul, American Phytopathological Society, Minnesota, USA.

99. Jones JB, Stall, RE, Zitter TA (1991) Compendium of tomato disease. American Phytopathological Society, St. Paul, Minnesota, USA.

100. Beckman CH (1987) The nature of wilt diseases of plants. American Phytopathological Society Press, St. Paul, Minnesota, 175.

101. Ros M, Hernandez MT, Garcia C, et al. (2005) Biopesticide effect of green compost against fusarium wilt on melon plants. $J$ Appl Microbiol 98: 845-854.

102. Anon (1994) Montreal protocol on substances that deplete the ozone layer: UNEP-Report of the Methy-Bromide Technical Option Committee. Environmental Protection Agency 430/ K94/029.

103. Ristaino JB, Thomas W (1997) Agriculture, methyl-bromide and the ozone hole: Can we fill the gaps. Plant Dis 81: 964- 977.

104. Biehne WL (1973) Curative action of foliar sprays of acidified benomyl suspension against Fusarium wilt of tomato. Plant Disease Reporter 57: 37-38.
105. Kendrick JB (1988) A view point on integrated pest management. Plant Disease 72: 647.

106. Groenewald S (2005) Biology, pathogenicity and diversity of Fusarium oxysporumf.sp.cubense. Unpublished Master Thesis, University of Pretoria.

107. Song W, Zhou L, Yang C, et al. (2004) Tomato Fusarium wilt and its chemical control strategies in a hydroponic system. Crop Protection 23: 243-247.

108. Alam SS, Sakamoto K, Amemiya Y, et al. (2010) Biocontrol of soil-borne Fusarium wilts of tomato and cabbage with a root colonizing fungus, Penicillium sp.

109. Amel AH, Soad MA, Ahmed Al (2010) Activation of tomato plant defense response against Fusarium wilt disease using Trichoderma harzianum and salicylic acid under greenhouse conditions. Research Journal of Agriculture and Biological Sciences 6: 328-338.

110. Ramaiah A, Kumar RH Garampalli (2015) In vitro antifungal activity of some plant extracts against Fusarium oxysporum $f$. sp. Lycopersici. Asian Journal of Plant Science and Research 5: 22-27.

111. Katan T (1997) Sporulation of Fusarium oxysporum f.sp.lycopersici on stem surfaces of tomato plants and aerial dissemination of inoculum. Phytopathology 87: 712-719.

112. Pritesh P, Subramanian RB (2011) PCR based method for testing Fusarium wilt resistance of tomato. African Journal of Basic and Applied Sciences 3: 222.

113. Kutama AS, Emechebe AM, Aliyu BS (2011) Field evaluation of some inoculation techniques on the incidence and severity of sorghum head smut (Sporisorium reilianum) in Nigerian Sudan savanna. Journal of Environment and Bio-Sciences 8: 292-296.

114. Kutama AS, Auyo MI, Umar S, et al. (2013) Reduction in growth and yield parameters of sorghum genotypes screened for loose smuts in Nigerian Sudan Savanna. World Journal of Agriciculture Research 1: 185-192.

115. Fuchs JG, Moenne Loccoz Y, Défago G (1997) Non-pathogenic fusarium oxysporum strain F047, induces resistance to fusarium wilt of tomato. Plant Diseases 81: 492-496.

116. Cotxarrera L, Trillas-Gay MI, Steinberg C, et al. (2002) Use of sewage sludge compost and trichoderma asperellum isolates to suppress fusarium wilt of tomato. Soil Biology and Biochemistry 34: 467-476.

117. Segarra G, Casanova E, Aviles M, et al. (2010) Trichoderma apserellum strain T34 controls fusarium wilt disease in tomato plants in soilless culture through competition for iron. Microbial Ecology in Health and Disease 59: 141-149.

118. De Corato U (2020) Disease-suppressive compost enhances natural soil supressiveness against soil-borne plant pathogens: A critical review. Rhizosphere 13, 100192.

119. El Komy MH, Amgad A, Saleh Eranthodi A, et al. (2015) Characterization of novel trichoderma asperellumisolates to select effective biocontrol agents against tomato Fusarium wilt. Plant Pathology Journal 31: 50-60.

120. Panteleev AA (1972) Trichoderma in the control of tracheomycoses. Review of Plant Pathology 52.

121. Gail A, Samsone I, levinsh G (2007) Ethylene is involved in Trichoderma-induced resistance of bean plants against Pseudomonas syringae, Acta Universitatis Latviensis 691: 59-70. 
Citation: Hassan HA (2020) Biology and Integrated Control of Tomato Wilt Caused by Fusarium oxysporum lycopersici: A Comprehensive Review under the Light of Recent Advancements. J Bot Res 3(1):84-99

122. Jayalakshmi SK, Raju S, Usha Rani S, et al. (2009) Trichoderma harzianum L1 as a potential source for lytic enzymes and elicitor of defense responses in chickpea (Cicer arietinum L.) against wilt disease caused by Fusarium oxysporum f. sp. ciceri. Australian Journal of Crop Sciences 3: 44-52.

123. El-Khallal SM (2007) Induction and modulation of resistance in tomato plants against fusarium wilt disease by nio agent fungi (Arbuscular mycorrhiza) and/or hormonal rlicitors (Jasmonic acid and salicylic acid): 1- changes in growth, some metabolic activities and endogenous hormones related to defence mechanism. Australian Journal of Basic and Applied Sciences 1: 691705.

124. Mandal S, Mallicka N, Mitraa A (2009) Salicylic acid-induced resistance to Fusarium oxysporum $\mathrm{f}$. $\mathrm{sp}$. Iycopersici in tomato. Plant Physiology and Biochemistry 47: 642-649.

125. Ko HS, Jin RD, Krishnan HB, et al. (2009) Biocontrol ability of lysobacter antibioticus HS124 against phytophthora blight is mediated by the production of 4-hydroxyphenylaceticacid and several lytic enzymes. Current Microbiology 59: 608-615.

126. Wisniewski M, Biles C, Droby S (1991) The use of yeast pichia guilliermondii biocontrol agent: Characterization of attachment to Botrytis cinerea. In: Wilson $\mathrm{CL}$, chalutz $\mathrm{E}$, biological control of postharvest diseases of fruit and vegetables. Proc. Workshop, US Department of Agriculture, 167-183.

127. Dey R, Pal KK, Bhatt DM, et al. (2004) Growth promotion and yield enhancement of peanut (Arachis hypogaea L) by application of plant growth promoting rhizobacteria. Microbiology Research 159: 371-394.

128. Harman GE, Howell CR, Viterbo A, Chet I, Lorito M (2004) Trichoderma species opportunistic, avirulent plant symbionts. Nature Reviews Microbiology 2: 43-56.

129. Castoria R, De Curtis F, Lima G (1997) $\beta$-1,3-glucanase activity of two saprophytic yeasts and possible mode of action as biocontrol agents against postharvest diseases. Postharvest Biology and Technology 12: 293-300.

130. Tseng S, Liu S, Yang H, et al. (2008) Proteomic study of biocontrol mechanisms of Trichoderma harzianum ETS 323 in response to Rhizoctonia solani. Journal of Agriculture and Food Chemistry 56: 6914-6922.

131. Li QL, Ning P, Zheng L, et al. (2011) Effects of volatile substances of Streptomyces globisporus JK-1 on control of Botrytis cinerea on tomato fruit. Biology Control 61: 113-120.

132. Rana SV, Pal R, Vaiphei K, et al. (2011) Garlic in health and disease. Nutrition Research Reviews 24: 60-71.

133. Obagwu J, Korsten L (2003) Control of citrus green and blue molds with garlic extracts. European Journal of Plant Pathology 109: 221-225.

134. Coventry E, Noble R, Whipps J (2001) Composting of onion and other vegetable wastes, with particular reference to Allium white rot. Rep Community Supported Agric 4862: 1-95.

135. Kimaru SK, Waudo SW, Monda E, et al. (2004) Effect of neem kernel cake powder (NKCP) on Fusarium wilt of tomato when used as soil amendment. Journal of Agriculture and Rural Development in the Tropics and Subtropics 105: 63-69.

136. Agbenin NO, Marley PS (2006) In-vitro assay of some plant extracts against Fusarium oxysporum f. sp. Iycopersici, causal agent of tomato wilt. Journal of Plant Protection Research 46: 215-220.
137. Hanaa RM, Abdou ZA, Salama DA, et al. (2011) Effect of Neem and willow aqueous extracts on Fusarium wilt disease in tomato seedlings: Induction of antioxidant defensive enzymes. Annals of Agricultural Sciences 58: 1-7.

138. Jun Ma, David M, Geiser H P, et al. (2013) Fusarium pathogenomics. Annual Review of Microbiology 67: 399-416.

139. Woo KS, Kim KS, Lamsal K, et al. (2009) An in vitro study of the antifungal effect of silver nanoparticles on oak wilt pathogen Raffaelea sp. Journal of Microbiology and Biotechnology 19: 760-764.

140. Braga PC, Sasso MD, Culici M, et al. (2007) Eugenol and thymol, alone or in combination, induce morphological alterations in the envelope of Candida albicans. Fitoterapia 78: 396-400.

141. Ohunakin AO, Bolanle OO (2017) In vitro antifungal activities of three aromatic plant extracts against Fusarium oxysporum Schlechtend. Fr. f. sp. lycopersici (Sacc.) causal organism of Fusarium wilt in tomato. Journal of Plant Sciences and Agriculture Research 1: 1.

142. Sreenu B, Zacharia S (2017) In vitro screening of plant extracts, Trichoderma harzianum and carbendazim against Fusarium oxysporium $\mathrm{f}$. sp. Iycopersici on tomato. International Journal of Current Microbiology 6: 818-823.

143. Pawar VC, VS Thaker (2007) Evaluation of the anti-Fusarium oxysporum $\mathrm{f}$. sp cicer and anti-Alternaria porri effects of some essential oils. World Journal of Microbiology and Biotechnology 23: 1099-1106.

144. Lawless J (1995) The Illustrated Encyclopedia of Essential Oils. Element Books 256.

145. Thabet M, Khalifa W (2018) Antifungal activities of clove oil against root rot and wilt pathogens of tomato plants. American-Eurasian Journal of Agriculture and Environmental Sciences 18: 105-114.

146. Ghosh R, Darin K, Nath P, et al. (2014) An overview of various piper species for their biological activities. International Journal of Pharma Research and Review 3: 67-75.

147. Abbasi BH, Ahmad N, Fazal H, et al. (2010) Conventional and modern propagation techniques in Piper nigrum. Journal of Medicinal Plants Research 4 1: 7-12.

148. Sidawi A, Azzam F, Abdulaziz A, et al. (2015) Control of Fusarium wilt and root rot of tomatoes using some plant extracts. Jordan Journal of Agricultural Sciences 11: 815-826.

149. Salem WM, Sayed W F, Abdel-Fatah H, et al. (2012) Assessment of compost for suppression of Fusarium oxysporum and improving Zea mays and Hibiscus sabdarriffa resistance to wilt diseases. African Journal of Biotechnology 11: 13403-13414.

150. Al-Hussain AA, Ahmed SM, Ismail AA (2010) Activation of tomato plant defense response against Fusarium wilt disease using Trichoderma harzianum and salicylic acid under greenhouse conditions. Journal of Agriculture and Biological Sciences 6: 328-338.

151. Naing KW, Anees M, Kim SJ, et al. (2014) Characterization of antifungal activity of Paenibacillus ehimensis KWN38 against soil-borne phytopathogenic fungi belonging to various taxonomic groups. Annals of Microbiology 64: 55-63.

152. Kouki S, Saidi N, Ben Rajeb A (2012) Control of Fusarium wilt of tomato caused by Fusarium oxysporum f.sp.radicis-lycopersici using mixture of vegetable and Posidonia oceanica compost. Applied and Environmental Soil Science. 
Citation: Hassan HA (2020) Biology and Integrated Control of Tomato Wilt Caused by Fusarium oxysporum lycopersici: A Comprehensive Review under the Light of Recent Advancements. J Bot Res 3(1):84-99

153. Moahmed AE Hassan, Kamal AM Abo-Elyousr (2013) Impact of compost application on Fusarium wilt disease incidence and microelements contents of basil plants. Archives of Phytopathology and Plant Protection 46: 1904-1918.
154. Almomany A, Alantary T (2008) Home and garden pests. Deanship of Academic Research, second edition, the University of Jordan press, Amman, Jordan.

155. AMPCO (2019) Tomato processing in Jordan. 